University of Nebraska - Lincoln

DigitalCommons@University of Nebraska - Lincoln

Nebraska Cooperative Fish \& Wildlife Research Nebraska Cooperative Fish \& Wildlife Research Unit -- Staff Publications

2007

\title{
A test of the cross-scale resilience model: Functional richness in Mediterranean-climate ecosystems
}

\author{
Donald A. Wardwell \\ University of Nebraska-Lincoln \\ Craig R. Allen \\ University of Nebraska-Lincoln, callen3@unl.edu \\ Garry D. Peterson \\ McGill University, Montreal, Quebec, Canada, garry.peterson@su.se \\ Andrew J. Tyre \\ University of Nebraska-Lincoln, atyre2@unl.edu
}

Follow this and additional works at: https://digitalcommons.unl.edu/ncfwrustaff

Part of the Other Environmental Sciences Commons

\footnotetext{
Wardwell, Donald A.; Allen, Craig R.; Peterson, Garry D.; and Tyre, Andrew J., "A test of the cross-scale resilience model: Functional richness in Mediterranean-climate ecosystems" (2007). Nebraska Cooperative Fish \& Wildlife Research Unit -- Staff Publications. 22.

https://digitalcommons.unl.edu/ncfwrustaff/22
}

This Article is brought to you for free and open access by the Nebraska Cooperative Fish \& Wildlife Research Unit at DigitalCommons@University of Nebraska - Lincoln. It has been accepted for inclusion in Nebraska Cooperative Fish \& Wildlife Research Unit -- Staff Publications by an authorized administrator of DigitalCommons@University of Nebraska - Lincoln. 


\title{
A test of the cross-scale resilience model: Functional richness in Mediterranean-climate ecosystems
}

\author{
Donald A. Wardwell ${ }^{a, *}$, Craig R. Allen ${ }^{b}$, Garry D. Peterson ${ }^{c}$, Andrew J. Tyre ${ }^{d}$ \\ ${ }^{a}$ Nebraska Cooperative Fish and Wildlife Research Unit, 122 Hardin Hall, University of Nebraska-Lincoln, \\ Lincoln, NE 68583, USA \\ ${ }^{\mathrm{b}}$ USGS - Nebraska Cooperative Fish and Wildlife Research Unit, 423 Hardin Hall, University of Nebraska-Lincoln, \\ Lincoln, NE 68583, USA \\ ${ }^{\mathrm{c}}$ Department of Geography \& McGill School of the Environment, McGill University, Montreal, Quebec, Canada H3A 2K6 \\ d School of Natural Resources, 416 Hardin Hall, University of Nebraska-Lincoln, Lincoln, NE 68583, USA
}

\section{A R T I C L E I N F O}

\section{Article history:}

Received 2 January 2007

Received in revised form

16 November 2007

Accepted 30 November 2007

Keywords:

Diversity

Body mass

Scale

Discontinuity

Gap rarity index

\begin{abstract}
A B S T R A C T
Ecological resilience has been proposed to be generated, in part, in the discontinuous structure of complex systems. Environmental discontinuities are reflected in discontinuous, aggregated animal body mass distributions. Diversity of functional groups within body mass aggregations (scales) and redundancy of functional groups across body mass aggregations (scales) has been proposed to increase resilience. We evaluate that proposition by analyzing mammalian and avian communities of Mediterranean-climate ecosystems. We first determined that body mass distributions for each animal community were discontinuous. We then calculated the variance in richness of function across aggregations in each community, and compared observed values with distributions created by 1000 simulations using a null of random distribution of function, with the same $n$, number of discontinuities and number of functional groups as the observed data. Variance in the richness of functional groups across scales was significantly lower in real communities than in simulations in eight of nine sites. The distribution of function across body mass aggregations in the animal communities we analyzed was non-random, and supports the contentions of the cross-scale resilience model.
\end{abstract}

(C) 2007 Elsevier B.V. All rights reserved.

\section{Introduction}

Ecological processes are scale-specific in their effects, and create heterogeneous landscapes with scale-specific structure and pattern (Turner et al., 2001). Spatial and temporal heterogeneity, in turn, contributes to the structure of animal communities. Spatial patterns affect an organism's ability to disperse, which in turn limits resource availability, gene flow, diversification, and other ecological processes (Turner et al.,
2001; Coulon et al., 2004; Vignieri, 2005). Spatial and temporal patterns within landscapes are also reflected in animal body mass distributions (Allen and Holling, 2002).

The Textural Discontinuity Hypothesis proposed that body mass distributions of animal communities reflect landscape structure (Holling, 1992). Holling proposed that landscapes are structured by a relatively few key processes, each operating at distinct spatial and temporal scales. The actions of those processes and the scales at which they operate are reflected in

\footnotetext{
* Corresponding author. Tel.: +1 402472 0449; fax: +1 4024722722.

E-mail addresses: wardwell@bigred.unl.edu (D.A. Wardwell), allencr@unl.edu (C.R. Allen), garry.peterson@mcgill.ca (G.D. Peterson), atyre2@unl.edu (A.J. Tyre).

1476-945X/\$ - see front matter (C) 2007 Elsevier B.V. All rights reserved.

doi:10.1016/j.ecocom.2007.11.001
} 
discontinuous patterns of structure and resource distribution upon landscapes. Discontinuous structure in landscapes may result in discontinuous, aggregated animal body mass patterns, which reflect the scales of structure available to animals within a given landscape. Discontinuous body mass distributions have been observed in numerous ecological systems and among several taxa, including birds, mammals, reptiles and amphibians, fish and bats (Allen and Holling, 2002).

Ecological resilience appears to be generated, in part, in the discontinuous structure of these complex systems (Peterson et al., 1998). Ecological resilience is a measure of the amount of change needed to transform an ecosystem from one set of processes and structures to a different set (Holling, 1973; Gunderson, 2000). An ecosystem with high resilience would require a substantial amount of energy to transform, whereas a low resilience system would transform with a relatively small amount of energy. Peterson et al. (1998) expanded upon Holling's Textural Discontinuity Hypothesis by proposing that functional diversity within body mass aggregations and redundancy of functional groups across body mass aggregations (i.e., scales) increases resilience. Resilience is increased by overlap of function by species of different functional groups operating at similar scales. A diversity of function within a scale provides a system with a wide latitude of response to a variety of different perturbations. Redundancy of functional groups across scales provides reinforcement of function, increasing resilience. Having functions reinforced at different scales provides a system with a robust control of perturbations when they exceed controls at a given scale.

The model Peterson et al. (1998) proposed has not been tested. However, the authors suggest several potential tests of their cross-scale resilience model, including analysis of empirical data, simulations, and field experimentation. They proposed testing the idea that ecological function is distributed across scales by analyzing the distribution of functional groups and determining if species of the same functional groups are dispersed across scales. In this paper, we evaluate this proposition by analyzing the distribution of function across scales in mammal and bird communities of several Mediterranean-climate ecosystems in various regions of the world. Specifically, we determined the variance in the distribution of functional richness across scales. Low variance in functional richness across scales would indirectly indicate both elements of the cross-scale resilience model, functional diversity within scales and redundancy across scales.

\section{Methods}

Despite being geographically and evolutionarily isolated with flora and fauna differing among regions, Mediterraneanclimate ecosystems are ecologically similar in structure and function (Di Castri and Mooney, 1973; Kalin Arroyo et al., 1995). They typically display high species diversity and are present in disparate regions of the world (Lavorel, 1999). Mediterraneanclimate ecosystems are characterized by wet winters, dry summers, and mild temperatures. These systems occur in subtropical latitudes on the western coast of continental land masses (California, Chile, southwestern Australia, and the
Cape Town area of South Africa) and the coast of the Mediterranean Sea (Davis and Richardson, 1995).

Species' distributions and body mass estimates were determined for bird and mammal communities in several Mediterranean-climate ecosystems. Avian community species' distributions were determined for Mediterranean ecosystems in San Diego County, California (Unitt, 1984), Spain (Cramp, 1978-1994), South Africa (Winterbottom, 1966) and southwestern Australia (Saunders and Ingram, 1995). All avian body masses were obtained from Dunning (1993), except for Spain which were determined from Cramp (1978-1994). Mammalian community species' distributions and body mass estimates were determined for Mediterranean ecosystems in California (Quinn, 1990; Silva and Downing, 1995), South Africa (Smithers, 1983; Silva and Downing, 1995), Spain (Cheylan, 1991), Chile (Miller, 1980, corroborated with Redford and Eisenberg, 1992), and southwestern Australia (Strahan, 1995). Only species that had established breeding populations in each respective region were included, and non-indigenous species were not included. Pelagic birds and bats were excluded because they interact with their environment differently than terrestrial species (Allen et al., 1999). In all cases, adult male and female body masses were averaged.

Each community was analyzed for discontinuities in their body mass distributions. All species within a community were ranked in order of body mass. The logs of the body masses were calculated, and discontinuities were determined with the gap rarity index (GRI) (Restrepo et al., 1997; Allen and Holling, 2002; Stow et al., 2007). The GRI uses the GRI statistic, which is the probability that the observed discontinuities in the body size spectrum occur by chance alone, to compare observed body mass distributions with a unimodal null distribution that is produced by a kernel density estimator (Silverman, 1981), which smoothes the observed data into a continuous null. This null distribution was then sampled 10000 times and an absolute discontinuity value:

$\mathrm{di}=\log 10(\mathrm{Mn}+1)-\log 10(\mathrm{Mn})$

was calculated for each species in each simulation. The ranked distribution of the observed body masses was compared with the distribution of the differences for the $n$th largest species from the simulations. The GRI for each species in the actual assemblage is the proportion of the simulated discontinuity values that were smaller than the observed discontinuity value. The significance of each GRI value was then determined by testing the null hypothesis that the value was drawn from a continuous distribution with an alpha of $<0.05$. Unusually large gap values were considered significant and determined the location of discontinuities that bound body mass aggregations. The results were confirmed by conducting a SAS Cluster analysis using the Ward option based on variance reduction (SAS Institute Inc., 1999).

Functional group classifications were determined for each species. A functional group is essentially the classification of an organism's ecological "role". For this study, we have defined functional groups as the combination of the species' diet and foraging strata. Data on diet and foraging strata were collected from published sources (Cramp, 1978-1994; Brown et al., 1982; Smithers, 1983; Blakers et al., 1984; Urban et al., 1986; Ehrlich et al., 1988; Fry et al., 1988; Jameson and Peeters, 
1988; Keith et al., 1992; Redford and Eisenberg, 1992; Strahan, 1995; Urban et al., 1997; Wilson and Ruff, 1999; Fry et al., 2000, 2004; MacDonald and Barrett, 2001). For species where more than one food source or foraging stratum were possible, the first item listed was used. The first listed item was assumed to be the most prominent food source in the species' diet. The diets of each species were then classified as one of seven categories: insectivore, piscivore, carnivore, granivore, nectarivore, herbivore, and omnivore. All invertebrate sources were categorized as insectivore, carrion feeders were classified as carnivorous, and fruits and nuts were considered herbivorous. In each community, a diet classification had to represent $5 \%$ of the total community or have an $n=5$, otherwise it was put into another diet classification, in order to maintain minimal numbers within each category for analysis. When necessary, insectivores and piscivores were classified as carnivores and granivores and nectarivores were classified as herbivores. Omnivores were classified according to the food source that was most present in their diets. The foraging stratum for each species was classified as one of the following: terrestrial and aquatic for both avian and mammalian fauna; aerial, bark, and foliage for avian fauna only; arboreal and fossorial for mammalian fauna only. The diets and foraging strata for each species were combined to create functional groups.

Body mass distributions were then analyzed to calculate the richness of function within size classes (i.e., the number of functional groups present within a given body mass aggregation), and the variance in richness of function across size classes. Although the cross-scale resilience model of Peterson et al. (1998) did not directly address the variance in the distribution of functional richness across scales, it follows that variance in richness should be low if diversity within scales and redundancy across scales are high. However, it is possible that even if observed variance in richness was low the identity of functions present could differ. We could not address that issue directly because of phylogenetic constraints on the body size of some functional groups. For example, granivores are more likely to be smaller animals. Thus, in our randomizations, which do not incorporate phylogenetic constraint, random distributions of individual functional groups will invariably be more dispersed than distributions in real communities. Therefore, we used the variance in richness of function across aggregations as an indirect assessement of the predictions of the cross-scale resilience model.

We used computer resampling to generate the distribution of variances that would be observed if there was no relationship between aggregations and functional groups. The basic dataset consists of a list of species, which aggregation they are in, and which functional group they belong to. The observed functional richness for the ith aggregation, $R_{i}$, is simply the number of unique functional groups observed in that aggregation. The estimated variance in functional richness across scales is then calculated as the variance of the $R_{i}$,

$\widehat{\operatorname{var}}(R)=\sum_{i} \frac{\left(R_{i}-\bar{R}\right)^{2}}{n-1}$

where $n$ is the number of aggregations present, and $\bar{R}$ is the average functional richness. To determine if this value is low, we generated 1000 permutations of the list of functional groups; a permutation randomly reorders a list without changing the elements of that list. The permutation preserves both the number of species in each aggregation, and the number of species in each functional group; only the relationship between functional groups and aggregations is randomized. For each permutation $j$ we calculated the variance of functional richness across scales in the same way as for the observed data. The observed variance is then ranked within the randomized distribution. Output from the simulations is the proportion of runs with variance above, equal, and below that of the observed variance of functional richness across aggregations. If the output shows a lower variance in the simulated distributions of functional diversity than in the observed, then the hypothesis proposed by Peterson et al. that functions tend to be distributed evenly across scales - is not supported. If the variance of functional richness across scales of the observed systems is smaller than the random distributions, the model of Peterson et al. (1998) is supported. The combined above and equal proportions (hereafter, "above") from the simulated runs were tested for correlation with number of species in the community $(N)$, number of body mass aggregations, and the number of functional groups.

\section{Results}

The body mass distributions of all the bird and mammal study communities were discontinuous (see Table 1). Distinct aggregations of body mass were detected among all sites with both methods. The number of aggregations ranged from four in the Chilean mammal community to 16 in the southwest Australian bird community. There were typically more aggregations in bird communities (ranging from 9 to 16) than in mammal communities (ranging from 4 to 9). This may be related to the higher number of species in the bird communities (81-141 species) than in mammal communities (27-65 species), and/or to differences in the manner in which terrestrial mammals and flighted birds interact with environmental structure.

The simulation runs produced greater proportions of variances ranked above or equal to the observed variance in all of the study sites, except Spain mammals (Table 1). The proportions of above and equal variances were higher in the bird communities of San Diego County $(p=0.996)$, Spain $(p=0.702)$, South Africa $(p=0.689)$, and southwestern Australia $(p=0.885)$, than in the mammal communities of California $(p=0.665)$, Spain $(p=0.152)$, South Africa $(p=0.582)$, Chile $(p=0.509)$ and southwestern Australia $(p=0.654)$. The ranking of above proportions were positively correlated with $N(r=0.65, p=0.059)$, number of body mass aggregations $(r=0.60, p=0.088)$, but not with the number of functional groups $(r=0.48, p=0.194)$ (Table 1$)$. The results of the correlation tests change dramatically when the data for Spain mammals, which is substantially different from the other eight replicates, is excluded. The ranking of above proportions, excluding Spain mammals, were positively correlated with $N(r=0.78, p=0.021)$, number of body mass aggregations $(r=0.72, p=0.044)$, and number of functional groups $(r=0.79, p=0.021)$. Because the sample sizes were small, the expected power of each individual simulation is not 
Table 1 - Provided is the ranking of observed variance in relation to 1000 simulations of a random null model (above + equal), the number of species in the community (N), number of body mass aggregations (No. Aggs), and number of functional groups (No. FnGrps)

\begin{tabular}{lccrr} 
& Above + equal & No. Aggs & No. FnGrps \\
\hline Chile mammals & 509 & 27 & 4 & 9 \\
California mammals & 665 & 32 & 6 & 7 \\
San Diego birds & 996 & 117 & 12 & 14 \\
South Africa birds & 689 & 81 & 9 & 9 \\
South Africa mammals & 582 & 65 & 14 & 6 \\
Spain birds & 702 & 119 & 16 & 12 \\
SW Australia birds & 885 & 141 & 6 & 7 \\
SW Australia mammals & 654 & 42 & 7 & 7 \\
Spain mammals & 152 & 50 & 0.6000 & 0.4776 \\
(r) w/Spain mammals & & 0.6484 & 0.7194 \\
(r) w/o Spain mammals & & 0.7818 & 0.7863 \\
\hline
\end{tabular}

Also included are the Pearson correlation results between above and equal proportions with $\mathrm{N}$, number of body mass aggregations, and number of functional groups. The results of the correlation tests excluding the Spain mammals data are included as well.

high. However, if there is genuinely no effect across all replicate ecosystems, then the proportion of combined above and equal distributions across all replicates will be drawn randomly from a uniform distribution between 0 and 1 . We used Fisher's test of uniform random numbers to determine if the observed results followed a uniform random distribution (e.g. McCarthy et al., 2001). The test statistic

$\mathrm{L}=-2 \sum_{i=1}^{n} \ln p_{i}$

has a Chi-square distribution with $2 n$ degrees of freedom for $n$ uniformly distributed random numbers (Fisher, 1954). The ranking of the observed variances in the lower half of the simulated variance distributions was an unlikely random outcome for a uniform distribution $(L=9.57, p=0.054)$. Removing the Spain mammals from the analysis yielded a stronger result $(L=5.803, p=0.009)$.

\section{Discussion}

Peterson et al.'s (1998) hypothesis which suggests that function should be non-randomly distributed within and across scales is supported by the results of our simulations (Table 1). Random simulations of functional distribution within and across body mass aggregations yielded distributions with higher variance of functional richness across scales than our data from Mediterranean-climate ecosystems. We did not test the relationship with resilience, as an effective method of estimating resilience is not yet known. However, our results do fit the predictions of the cross-scale resilience model proposed by Peterson et al. (1998), without explicitly testing it. The rankings of the observed data in the distribution generated by the null model were higher in avian communities than in mammalian communities. The four avian communities also had more species, more body mass aggregations, and more functional groups than did the mammalian communities. The correlations identify a positive relationship between these three variables and the rankings of the observed data. As the number of species, body mass classes, or functional groups increases, so does the proportion of above variances in the simulated runs. The relationship is substantially stronger when the Spain mammal data are excluded.

Peterson et al. (1998) suggest that the process of interspecific competition could be the mechanism driving a nonrandom distribution of function within and across scales. Species of the same functional group, for example foliage insectivores, are more likely to interact with each other and compete than with members of other functional groups. Similarly, species exploiting their environment at the same range of scale, that is, species with body mass that place them in the same body mass aggregation, are more likely to interact with each other, and potentially compete, than with species that exploit their environment at larger or smaller scales. Thus, coexistence of species within the same functional group will be facilitated if they exploit their environment at different scales, and species operating at the same scale are likely to be member of different functional groups. Compartmentalization of species interactions by scale, driving within-scale diversity and cross-scale redundancy, is likely to be adaptive because it creates resilient and thus persistent species combinations, by maximizing response diversity within scales and by providing a robust check to perturbations that tend to scale up, such as insect outbreaks.

Because of the complex and unpredictable nature of ecosystems, the task of increasing, or even maintaining, ecological resilience is daunting. Estimating or predicting resilience is one of the challenges ecologists face in the management of ecosystems. Recent improvements in estimating ecological resilience have been made with the use of models, however, these methods are still relatively new and their utility has not been effectively tested (Peterson, 2002). Allen et al. (2005) propose that resilience may be operationalized in the discontinuous structure of complex systems. They suggest that numbers of body mass aggregations, richness of function within and across aggregations, and the location of species turnover are measures that can be used to determine the relative resilience of system. Our analysis shows that ecological systems exhibit a non-random distribution of function within and across aggregations. Documenting a non-random distribution of function across aggregations is 
key for developing effective, quantifiable methods of operationalizing resilience in the discontinuous structure of ecological systems.

Our simulations determine if richness is spread evenly across body mass aggregations, but does not determine whether a particular functional group is spread across aggregations more than expected. The latter is assumed to follow the former; however we do not explicitly test this. Also, we have not accounted for phylogenetic constraints on body mass. Functional groups may be constrained to species of certain body masses. For example, we can predict a granivorous, foliage-gleaning bird to be of a relatively small body mass, or an aerial carnivore to be amongst the larger birds in a community. On the other hand, these constraints are not hard and fast. Baleen whales are especially large insectivores, feeding on tiny invertebrates. Likewise, fire ants (Solenopsis invicta) may feed upon animals much larger than themselves (Allen et al., 2004). Regardless, it is not necessary to have every functional group spread across every aggregation in order to support Peterson et al.'s (1998) hypothesis. Our tests confirm that functional groups are more dispersed than would be expected if they were randomly assembled.

As landscapes globally become increasingly altered by humans, animal communities also will change. Improving our knowledge of the relationship between landscape structure and animal body mass distributions may enhance our understanding of ecological resilience and the role biodiversity plays in maintaining resilience. Many current management strategies fail because they attempt to control disturbances or fluctuations, or manage for only one or a few species (Gunderson, 2000; Folke et al., 2004). These strategies do not account for the unpredictable nature of complex ecosystems. By maintaining or increasing resilience in these systems, the likelihood of transformations to undesired, alternative states of ecological processes and structure may be reduced. We must also adapt to the gradual, and often unexpected, changes that affect resilience using approaches that operate at multiple scales (Gunderson, 2000; Gunderson and Holling, 2002; Folke et al., 2004).

In order to develop more advanced methods of estimating resilience, it is important to understand how resilience is generated within ecosystems. Peterson et al. (1998) believed that resilience is generated, in part, in the discontinuous structure of these systems through functional diversity of species within scales and the redundancy of function across scales. Our study supports this proposition, and together with future empirical and field tests may help provide a thorough understanding of how ecological resilience is generated. By determining the body mass distributions and functional makeup of animal communities, we may be able to predict which species are at the highest risks and how to best maintain an ecosystem's resilience. Using and improving these tools may be a key element to better management of ecological systems in the future.

\section{Acknowledgements}

Support was provided by the James S. McDonnell Foundation 21st Century Research Award/Studying Complex Systems (Allen). The Nebraska Cooperative Fish and Wildlife Research Unit is jointly supported by a cooperative agreement between the United States Geological Survey-Biological Resources Division, the Nebraska Game and Parks Commission, the University of Nebraska-Lincoln and the Wildlife Management Institute.

\section{Appendix A}

Bird species distribution for Mediterranean-climate: San Diego County, California, USA; Spain; southwestern Australia; South Africa (Tables A1-A4) and mammal species distribution for Mediterranean-climate: California, USA; South Africa; southwestern Australia; Chile; Spain (Tables A5-A9).

\section{Table A1 - Bird species distribution for Mediterranean-climate San Diego County, California, USA}

\begin{tabular}{lccc} 
Latin name & Body mass & Aggregation & Functional group \\
\hline Archilochus costae & 0.491 & 1 & HeAe \\
Cynanthus latirostris & 0.491 & 1 & HeAe \\
Archilochus alexandri & 0.531 & 1 & HeAe \\
Archilochus anna & 0.623 & 1 & HeAe \\
Polioptila melanura & 0.708 & 1 & InFo \\
Psaltriparius minimus & 0.724 & 1 & InFo \\
Polioptila caerulea & 0.778 & 1 & InFo \\
Wilsonia pusilla & 0.839 & 2 & InFo \\
Dendroica nigrescens & 0.922 & 2 & InFo \\
Vireo bellii pusillus & 0.929 & 2 & InFo \\
Vermivora celata & 0.954 & 2 & InFo \\
Carduelis psaltria & 0.978 & 2 & InFo \\
Dendroica petechia & 0.978 & 2 & GrFo \\
Thryomanes bewickii & 0.996 & 2 & InTe \\
Empidonax difficilis & 1.000 & 2 & InAe \\
Geothlypis trichas & 1.004 & 2 & InFo \\
Parus gambeli baileyae & 1.033 & 2 & InFo \\
Troglodytes aedon & 1.037 & InTe
\end{tabular}


Table A1 (Continued)

Latin name

Body mass

Aggregation

Functional group

Carduelis lawrencei

Cistothorus palustris

1.039

1.051

1.064

Spizella atrogularis cana

1.076

Spizella passerina

1.090

Salpinctes mexicanus

1.100

Contopus sordidulus

Vireo vicinior

1.107

Carduelis tristis

1.107

Empidonax traillii

1.111

1.127

Tachycineta thalassina

1.151

Chamaea fasciata

1.166

Vireo giluus

1.170

Stelgidopteryx ruficollis

1.182

Passerina amoena

1.190

Vireo solitarius

1.220

Ammodramus savannarum

1.230

Parus inornatus

1.243

Sayornis nigricans

1.271

Aimophila ruficeps

1.272

Aimophila belli

1.286

Zonotrichia melodia

1.291

Sitta carolinensis

1.324

Sayornis saya

1.326

Carpodacus mexicanus

1.330

Hirundo pyrrhonota

1.334

Phainopepla nitens

Icterus cucullatus

1.380

1.386

Carpodacus purpureus

1.396

Icteria virens auricollis $\quad 1.403$

Dendrocopos pubescens $\quad 1.431$

Myiarchus cinerascens $\quad 1.435$

Sialia mexicana $\quad 1.448$

Passerina caerulea

1.453

Chondestes grammacus

1.462

Pipilo chlorurus

1.468

Catharus ustulatus

Eremophila alpestris

1.489

1.496

1.507

Aeronautes saxatalis

1.509

Passerella iliaca

1.526

1.583

1.590

Campylorhynchus brunneicapillus

1.598

1.610

Pipilo erythrophthalmus

1.623

Molothrus ater $\quad 1.642$

Pipilo fuscus senicula $\quad 1.647$

Tyrannus vociferans $\quad 1.659$

Lanius ludovicianus $\quad 1.676$

Mimus polyglottos

Progne subis subis

Chordeiles acutipennis

Phalaenoptilus nuttallii

1.686

1.694

1.698

1.713

Agelaius phoeniceus

1.721

Agelaius tricolor

1.769

1.797

1.806

Coccyzus americanus

Xanthocephalus xanthocephalus

1.810

1.873

$\begin{array}{ll}\text { Aphelocoma coerulescens } & 1.904 \\ \text { Melanerpes formicivorus } & 1.906\end{array}$

$\begin{array}{ll}\text { Melanerpes formicivorus } & 1.906 \\ \text { Rallus limicola limicola } & 1.914\end{array}$

Toxostoma redivivum

1.926

1.936
1.985

Ixobrychus exilis hesperis

2

GrFo

InTe

InFo

InTe

InTe

InTe

InAe

InFo

GrFo

InAe

InAe

InFo

InFo

InAe

InTe

InFo

InTe

InAe

InAe

InTe

InTe

InTe

$\mathrm{InBa}$

InAe

GrTe

InAe

HeFo

InFo

GrTe

InFo

InBa

InAe

InAe

InTe

GrTe

InTe

InFo

GrTe

InAe

InTe

InFo

InBa

InTe

InAe

InTe

InFo

InTe

GrTe

InAe

InAe

InTe

InAe

InAe

InAe

InTe

InTe

InTe

InFo

InTe

GrTe

OmTe

$\mathrm{OmBa}$

InAq

InTe

$\mathrm{CaAq}$

Charadrius vociferus

1.985

InTe

Please cite this article in press as: Wardwell, D.A. et al., A test of the cross-scale resilience model: Functional richness in Mediterraneanclimate ecosystems, Ecol. Complex. (2008), doi:10.1016/j.ecocom.2007.11.001 


\section{Table A1 (Continued)}

\begin{tabular}{|c|c|c|c|}
\hline Latin name & Body mass & Aggregation & Functional group \\
\hline Sturnella neglecta & 2.003 & 9 & InTe \\
\hline Falco sparverius & 2.063 & 9 & InAe \\
\hline Zenaida macroura & 2.076 & 9 & GrTe \\
\hline Colaptes auratus & 2.102 & 9 & InTe \\
\hline Cyanocitta stelleri & 2.107 & 9 & OmTe \\
\hline Otus kennicottii & 2.155 & 9 & $\mathrm{CaAe}$ \\
\hline Athene cunicularia & 2.190 & 9 & InAe \\
\hline Callipepla gambelii & 2.220 & 9 & GrTe \\
\hline Callipepla californica & 2.238 & 9 & GrTe \\
\hline Ardeola striata anthonyi & 2.326 & 10 & $\mathrm{CaAq}$ \\
\hline Callipepla picta & 2.367 & 10 & GrTe \\
\hline Asio otus wilsonianus & 2.418 & 10 & $\mathrm{CaAe}$ \\
\hline Elanus leucurus & 2.522 & 11 & $\mathrm{CaAe}$ \\
\hline Egretta ibis ibis & 2.529 & 11 & InTe \\
\hline Geoccyx californianus & 2.575 & 11 & InTe \\
\hline Columba fasciata & 2.593 & 11 & HeFo \\
\hline Circus cyaneus hudsonius & 2.639 & 11 & $\mathrm{CaAe}$ \\
\hline Accipiter cooperii & 2.642 & 11 & $\mathrm{CaAe}$ \\
\hline Corvus brachyrhynchos & 2.651 & 11 & OmTe \\
\hline Tyto alba pratincola & 2.719 & 11 & $\mathrm{CaAe}$ \\
\hline Buteo lineatus & 2.747 & 11 & $\mathrm{CaAe}$ \\
\hline Strix occidentalis & 2.785 & 11 & $\mathrm{CaAe}$ \\
\hline Falco mexicanus & 2.850 & 11 & $\mathrm{CaAe}$ \\
\hline Dendrocygna bicolor & 2.851 & 11 & $\mathrm{HeAq}$ \\
\hline Falco peregrinus & 2.893 & 11 & $\mathrm{CaAe}$ \\
\hline Nycticorax nycticorax & 2.946 & 11 & $\mathrm{CaAg}$ \\
\hline Buteo swainsoni & 2.995 & 11 & $\mathrm{CaAe}$ \\
\hline Buteo jamaicensis & 3.052 & 11 & $\mathrm{CaAe}$ \\
\hline Corvus corax clarionensis & 3.079 & 11 & OmTe \\
\hline Bubo virginianus & 3.117 & 11 & $\mathrm{CaAe}$ \\
\hline Cathartes aura & 3.166 & 11 & $\mathrm{CaAe}$ \\
\hline Aquila chrysaetos & 3.623 & 12 & $\mathrm{CaAe}$ \\
\hline Gymnogyps californicus & 4.004 & 12 & $\mathrm{CaAe}$ \\
\hline
\end{tabular}

Each distribution includes Latin names, log10-transformed body masses, body mass aggregation membership, and functional group code used in richness simulations. The first two letters (prefix) of the functional group code represent the diet component and the latter two letters (suffix) represent foraging strata. Key to prefixes: $\mathrm{Ca}=$ carnivore; $\mathrm{Gr}=$ granivore; He = herbivore; $\mathrm{In}=$ insectivore; $\mathrm{Ne}=\mathrm{nectarivore}$; Om = omnivore. Key to suffixes: $\mathrm{Ae}=$ aerial; $\mathrm{Aq}=$ aquatic; $\mathrm{Ar}=$ arboreal; $\mathrm{Ba}=$ bark; $\mathrm{Fo}=$ foliage; $\mathrm{Fs}=$ fossorial; $\mathrm{Te}=$ terrestrial.

Table A2 - Bird species distribution for Mediterranean-climate Spain

\begin{tabular}{lccc} 
Latin name & Body mass & Aggregation & Functional group \\
\hline Aegithalos caudatus & 0.895 & 1 & InFo \\
Phylloscopus bonelli & 0.913 & 1 & InFo \\
Certhia brachydactyla & 0.914 & 1 & InBa \\
Cisticola juncidis & 0.940 & 1 & InTe \\
Sylvia cantillans & 0.964 & 1 & InFo \\
Troglodytes troglodytes & 0.973 & 1 & InFo \\
Sylvia undata & 0.973 & 1 & InTe \\
Parus ater & 0.987 & 1 & InFo \\
Sylvia conspicillata & 1.004 & 1 & InFo \\
Parus caeurleus & 1.029 & 1 & InFo \\
Hippolais pallida & 1.039 & 1 & 1 \\
Hippolais polyglotta & 1.041 & 1 & InFo \\
Serinus serinus & 1.077 & 1 & InFo \\
Parus cristatus & 1.099 & 1 & GrTe \\
Riparia riparia & 1.119 & 1 & InFo \\
Cettia cetti & 1.125 & 1 & InAe \\
Sylvia melanocephala & 1.129 & 1 & InTe \\
Saxicola torquata & 1.161 & 2 & InTe \\
Muscicapa striata & 1.197 & 2 & InAe \\
Carduelis carduelis & 1.210 & 2 & InAe \\
Phoenicurus ochruros & 1.211 & GrTe & InTe
\end{tabular}

Please cite this article in press as: Wardwell, D.A. et al., A test of the cross-scale resilience model: Functional richness in Mediterraneanclimate ecosystems, Ecol. Complex. (2008), doi:10.1016/j.ecocom.2007.11.001 
Table A2 (Continued)

Latin name

Oenanthe hispanica

Erithacus rubecula

Motacilla cinerea

Motacilla flava

Parus major

Hirundo rustica

Carduelis cannabina

Delichon urbica

Sylvia atricapilla

Luscinia megarhynchos

Motacilla alba

Sylvia hortensis

Fringilla coelebs

Calandrella brachydactyla

Hirundo daurica

Ptyonprogne rupestris

Emberiza cia

Calandrella rufescens

Cercotrichas galactotes

Oenanthe oenanthe

Emberiza cirlus

Lullula arborea

Carduelis chloris

Anthus campestris

Passer domesticus

Acrocephalus arundinaceus

Lanius senator

Alcedo atthis

Galerida theklae

Alauda arvensis

Oenanthe leucura

Apus apus

Galerida cristata

Milaria calandra

Merops apiaster

Monticola solitarius

Coccothraustes coccothraustes

Cinclus cinclus

Melanocorypha calandra

Larius excubitor

Turnix sylvatica

Upupa epops

Caprimulgus ruficollis

Oriolus oriolus

Glareola pratincola

Dendrocopos major

Caprimulgus europaeus

Otus scops

Sturnus unicolor

Turdus merula

Coturnix coturnix

Apus (Tachymarptis) melba

Rallus aquaticus

Cuculus canorus

Turdus viscivorus

Tachybaptus ruficollis

Streptopelia turtur

Coracias garrulus

Ixobrychus minutus

Falco naumanni

Clamator glandarius

Athene noctua

Garrulus glandarius

Picus viridis

Accipiter nisus

Falco subbuteo
Body mass

Aggregation

Functional group

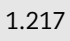

1.223

1.261

1.268

1.272

1.281

1.290

1.291

1.291

1.312

1.322

1.324

1.331

1.347

1.347

1.364

1.366

1.377

1.387

1.389

1.408

1.417

1.418

1.459

1.478

1.479

1.512

1.550

1.566

1.585

1.600

1.630

1.650

1.694

1.741

1.756

1.763

1.778

1.783

1.802

1.813

1.830

1.836

1.847

1.904

1.906

1.929

1.930

1.938

1.967

2.007

2.017

2.063

2.065

2.071

2.130

2.135

2.167

2.169

2.182

2.186

2.196

2.214

2.244

2.310

2.324
InTe

InTe

InTe

InTe

InFo

InAe

GrTe

InAe

InFo

InTe

InTe

InFo

GrTe

InTe

InAe

InAe

GrTe

InTe

InTe

InTe

GrTe

InTe

GrTe

InTe

GrTe

InFo

InAe

$\mathrm{CaAe}$

InTe

InTe

InTe

InAe

GrTe

GrTe

InAe

InAe

GrFo

InAq

InTe

InAe

GrTe

InTe

InAe

InFo

InAe

InBa

InAe

InAe

InTe

InTe

GrTe

InAe

InAq

InFo

InTe

InAq

GrTe

InAe

$\mathrm{CaAq}$

InAe

InFo

$\mathrm{CaAe}$

InFo

InTe

$\mathrm{CaAe}$

$\mathrm{CaAe}$

Please cite this article in press as: Wardwell, D.A. et al., A test of the cross-scale resilience model: Functional richness in Mediterraneanclimate ecosystems, Ecol. Complex. (2008), doi:10.1016/j.ecocom.2007.11.001 


\section{Table A2 (Continued)}

\begin{tabular}{|c|c|c|c|}
\hline Latin name & Body mass & Aggregation & Functional group \\
\hline Falco tinnunculus & 2.366 & 10 & $\mathrm{CaAe}$ \\
\hline Corvus monedula & 2.376 & 10 & InTe \\
\hline Pterocles alchata & 2.376 & 10 & GrTe \\
\hline Asio Otus & 2.423 & 10 & $\mathrm{CaAe}$ \\
\hline Tyto alba & 2.454 & 10 & $\mathrm{CaAe}$ \\
\hline Columba livia & 2.469 & 10 & GrTe \\
\hline Gallinula chloropus & 2.477 & 10 & $\mathrm{HeAq}$ \\
\hline Circus pygargus & 2.499 & 10 & $\mathrm{CaAe}$ \\
\hline Pterocles orientalis & 2.608 & 11 & GrTe \\
\hline Strix aluco & 2.663 & 11 & $\mathrm{CaAe}$ \\
\hline Burhinus oedicnemus & 2.665 & 11 & InAq \\
\hline Alectoris rufa & 2.679 & 11 & GrTe \\
\hline Columba palumbus & 2.689 & 11 & HeTe \\
\hline Corvus corone & 2.691 & 11 & InTe \\
\hline Podiceps cristatus & 2.889 & 12 & $\mathrm{CaAq}$ \\
\hline Miluus migrans & 2.918 & 12 & $\mathrm{CaAe}$ \\
\hline Hieraaetus pennatus & 2.925 & 12 & $\mathrm{CaAe}$ \\
\hline Buteo buteo & 2.929 & 12 & $\mathrm{CaAe}$ \\
\hline Ardea purpurea & 2.941 & 12 & $\mathrm{CaAq}$ \\
\hline Falco peregrinus & 2.949 & 12 & $\mathrm{CaAe}$ \\
\hline Accipiter gentilis & 2.967 & 12 & $\mathrm{CaAe}$ \\
\hline Milvus milvus & 3.020 & 12 & $\mathrm{CaAe}$ \\
\hline Corvus corax & 3.054 & 12 & CaTe \\
\hline Circaetus gallicus & 3.230 & 13 & $\mathrm{CaAe}$ \\
\hline Hieraaetus fasciatus & 3.312 & 13 & $\mathrm{CaAe}$ \\
\hline Neophron percnopterus & 3.320 & 13 & $\mathrm{CaAe}$ \\
\hline Bubo bubo & 3.347 & 13 & $\mathrm{CaAe}$ \\
\hline Aquila heliaca & 3.514 & 14 & $\mathrm{CaAe}$ \\
\hline Ciconia ciconia & 3.538 & 14 & CaTe \\
\hline Aquila chrysaetos & 3.642 & 14 & $\mathrm{CaAe}$ \\
\hline Otis tarda & 3.862 & 14 & InTe \\
\hline Gyps fulvus & 3.870 & 14 & $\mathrm{CaAe}$ \\
\hline
\end{tabular}

\section{Table A3 - Bird species distribution for Mediterranean-climate southwestern Australia}

\begin{tabular}{lccc} 
Latin name & Body mass & Aggregation & Functional group \\
\hline Smicrornis brevirostris & 0.708 & 1 & GrFo \\
Gerygone fusca & 0.783 & 1 & InFo \\
Malurus leucopterus & 0.785 & 1 & InFo \\
Acanthiza inornata & 0.845 & 2 & InTe \\
Poephila guttata & 0.845 & 2 & GrTe \\
Acanthiza uropygialis & 0.874 & 2 & InFo \\
Stipiturus malachurus & 0.879 & 2 & InTe \\
Acanthiza apicalis & 0.881 & 2 & InFo \\
Certhionyx niger & 0.892 & 2 & NeFo \\
Petroica goodenovii & 0.903 & 2 & InAe \\
Rhipidura fuliginosa & 0.903 & 2 & InAe \\
Malurus lamberti & 0.903 & 2 & InFo \\
Dicaeum hirundinaceum & 0.903 & 2 & HeTe \\
Acanthiza chrysorrhoa & 0.944 & 3 & InFo \\
Pardalotus punctatus & 0.964 & 3 & InFo \\
Malurus pulcherrimus & 0.978 & 3 & InFo \\
Petroica multicolor & 0.982 & 3 & InTe \\
Malurus splendens & 1.000 & 3 & InFo \\
Malurus elegans & 1.000 & 3 & InFo \\
Ephthianura tricolor & 1.024 & 3 & InTe \\
Acanthorhynchus superciliosus & 1.033 & 3 & NeFo
\end{tabular}

Please cite this article in press as: Wardwell, D.A. et al., A test of the cross-scale resilience model: Functional richness in Mediterraneanclimate ecosystems, Ecol. Complex. (2008), doi:10.1016/j.ecocom.2007.11.001 
Table A3 (Continued)

Latin name

Body mass

Aggregation

Functional group

Sericornis brunneus

Cecropis ariel

1.052

Emblema oculata

1.053

Daphoenositta chrysoptera

1.070

1.076

Ephthianura albifrons

1.079

Pardalotus striatus

1.086

Aphelocephala leucopsis

1.101

Sericornis frontalis

1.107

Lichmera indistincta

1.114

Sericornis cautus

1.153

Melithreptus brevirostris $\quad 1.164$

Hirundo neoxena $\quad 1.167$

Melithreptus lunatus

1.167
1.167

Cheramoeca leucosternum

1.170

Cecropis nigricans

1.175

Microeca leucophaea

1.196

Lichenostomus ornatus

1.250

Phylidonyris albifrons

1.255

Pachycephala rufiventris $\quad 1.258$

Phylidonyris nigra $\quad 1.262$

Phylidonyris melanops

1.267

Lichenostomus cracticus

1.292

Lichenostomus penicillatus

1.297

Phylidonyris novaehollandiae

1.301

Sericornis fuliginosus

1.319

Melanodryas cucullata

1.326

Eopsaltria griseogularis

1.336

Amytornis textilis

1.356

Chrysococcyx basalis

1.358

Lichenostomus leucotis

1.364

Myiagra inquieta

1.380

Anthus novaeseelandiae

1.384

Lichenostomus virescens

1.391

Chrysococcyx lucidus

Cinclorhamphus mathewsi

1.394

1.398

Certhionyx variegatus $\quad 1.414$

Lalage sueurii $\quad 1.415$

Rhipidura leucophrys $\quad 1.442$

Cinclorhamphus cruralis $\quad 1.447$

Falcunculus frontatus $\quad 1.456$

Chrysococcyx osculans $\quad 1.458$

Merops ornatus $\quad 1.459$

Melopsittacus undulatus $\quad 1.462$

Pachycephala inornata $\quad 1.515$

Pachycephala pectoralis $\quad 1.515$

Climacteris rufa $\quad 1.526$

Pomatostomus superciliosus $\quad 1.544$

Artamus cinereus 1.544

Artamus personatus $\quad 1.549$

Geopelia cuneata $\quad 1.550$

Drymodes brunneopygia $\quad 1.568$

Artamus cyanopterus $\quad 1.602$

Turnix velox 1.613

Halcyon sancta $\quad 1.620$

Neophema elegans 1.633

Glossopsitta porphyrocephala $\quad 1.641$

Acanthagenys rufogularis $\quad 1.643$

Cuculus pyrrhophanus $\quad 1.679$

Aegotheles cristatus $\quad 1.699$

Halcyon pyrrhopygia $\quad 1.719$

Psephotus varius $\quad 1.778$

Oreoica gutturalis $\quad 1.792$

Platycercus icterotis $\quad 1.801$

Manorina flavigula $\quad 1.829$

Cinclosoma castanotum $\quad 1.865$

Anthochaera chrysoptera

1.865
1.871

InTe

$\operatorname{InAe}$

GrFo

InBa

InTe

InFo

InTe

InTe

$\mathrm{NeFo}$

InTe

NeFo

InAe

NeFo

InAe

InAe

InAe

$\mathrm{NeFo}$

NeFo

InTe

NeFo

$\mathrm{NeFo}$

InFo

HeFo

$\mathrm{NeFo}$

InFo

InAe

InTe

GrTe

InFo

HeFo

InAe

InTe

NeFo

InFo

GrTe

NeFo

InTe

InAe

InTe

InBa

InFo

InAe

GrTe

InTe

InTe

InBa

InTe

InAe

InAe

GrTe

InTe

InAe

GrTe

InTe

GrTe

HeFo

InAe

InTe

InTe

InTe

GrTe

InTe

GrFo

$\mathrm{NeFo}$

GrTe

NeFo

Please cite this article in press as: Wardwell, D.A. et al., A test of the cross-scale resilience model: Functional richness in Mediterraneanclimate ecosystems, Ecol. Complex. (2008), doi:10.1016/j.ecocom.2007.11.001 


\section{Table A3 (Continued)}

\begin{tabular}{|c|c|c|c|}
\hline Latin name & Body mass & Aggregation & Functional group \\
\hline Colluricincla harmonica & 1.879 & 9 & InFo \\
\hline Cuculus pallidus & 1.934 & 10 & HeTe \\
\hline Turnix varia & 1.944 & 10 & GrTe \\
\hline Caprimulgus guttatus & 1.945 & 10 & InAe \\
\hline Grallina cyanoleuca & 1.949 & 10 & InTe \\
\hline Nymphicus hollandicus & 1.954 & 10 & GrTe \\
\hline Cracticus torquatus & 1.966 & 10 & InFo \\
\hline Peltohyas australis & 1.966 & 10 & InTe \\
\hline Coracina novaehollandiae & 1.970 & 10 & InTe \\
\hline Coturnix australis & 1.974 & 10 & GrTe \\
\hline Polytelis anthopeplus & 2.057 & 11 & GrTe \\
\hline Anthochaera carunculata & 2.097 & 11 & NeFo \\
\hline Purpureicephalus spurius & 2.107 & 11 & GrFo \\
\hline Barnardius zonarius & 2.125 & 11 & NeFo \\
\hline Coracina maxima & 2.126 & 11 & InTe \\
\hline Falco cenchroides & 2.193 & 12 & InAe \\
\hline Cracticus nigrogularis & 2.193 & 12 & InTe \\
\hline Ninox novaeseelandiae & 2.241 & 12 & InAe \\
\hline Accipiter cirrhocephalus & 2.255 & 12 & $\mathrm{CaAe}$ \\
\hline Ocyphaps lophotes & 2.264 & 12 & GrTe \\
\hline Vanellus tricolor & 2.265 & 12 & InTe \\
\hline Phaps elegans & 2.301 & 12 & GrTe \\
\hline Elanus notatus & 2.398 & 13 & $\mathrm{CaAe}$ \\
\hline Falco longipennis & 2.403 & 13 & $\mathrm{CaAe}$ \\
\hline Phaps chalcoptera & 2.491 & 13 & GrFo \\
\hline Cacatua leadbeateri & 2.491 & 13 & HeFo \\
\hline Gymnorhina tibicen & 2.497 & 13 & InTe \\
\hline Cacatua roseicapilla & 2.505 & 13 & GrTe \\
\hline Podargus strigoides & 2.544 & 13 & InTe \\
\hline Circus assimilis & 2.623 & 14 & InAe \\
\hline Ninox connivens & 2.665 & 14 & $\mathrm{CaAe}$ \\
\hline Lophoictinia isura & 2.700 & 14 & $\mathrm{CaAe}$ \\
\hline Accipiter fasciatus & 2.708 & 14 & $\mathrm{CaAe}$ \\
\hline Tyto alba & 2.719 & 14 & $\mathrm{CaAe}$ \\
\hline Cacatua sanguinea & 2.720 & 14 & GrTe \\
\hline Falco berigora & 2.740 & 14 & $\mathrm{CaTe}$ \\
\hline Ardea novaehollandiae & 2.742 & 14 & $\mathrm{CaAq}$ \\
\hline Tyto novaehollandiae & 2.785 & 14 & $\mathrm{CaAe}$ \\
\hline Calyptorhynchus magnificus & 2.796 & 14 & HeFo \\
\hline Ardea pacifica & 2.813 & 14 & $\mathrm{CaAg}$ \\
\hline Corvus coronoides & 2.829 & 14 & CaTe \\
\hline Burhinus magnirostris & 2.836 & 14 & InTe \\
\hline Cacatua tenuirostris & 2.869 & 14 & HeTe \\
\hline Falco peregrinus & 2.893 & 14 & $\mathrm{CaAe}$ \\
\hline Haliastur sphenurus & 2.903 & 14 & $\mathrm{CaAe}$ \\
\hline Calyptorhynchus funereus & 2.904 & 14 & GrFo \\
\hline Hieraaetus morphnoides & 2.924 & 14 & $\mathrm{CaAe}$ \\
\hline Chenonetta jubata & 2.940 & 14 & HeTe \\
\hline Tadorna tadornoides & 3.111 & 15 & $\mathrm{HeAq}$ \\
\hline Threskiornis spinicollis & 3.255 & 15 & InTe \\
\hline Leipoa ocellata & 3.273 & 15 & HeTe \\
\hline Aquila audax & 3.544 & 16 & $\mathrm{CaAe}$ \\
\hline Ardeotis australis & 3.799 & 16 & InTe \\
\hline Dromaius novaehollandiae & 4.494 & 16 & $\mathrm{HeTe}$ \\
\hline
\end{tabular}

Each distribution includes Latin names, log10-transformed body masses, body mass aggregation membership, and functional group code used in richness simulations. The first two letters (prefix) of the functional group code represent the diet component and the latter two letters (suffix) represent foraging strata. Key to prefixes: $\mathrm{Ca}=$ carnivore; $\mathrm{Gr}=$ granivore; He = herbivore; $\mathrm{In}=$ insectivore; $\mathrm{Ne}=\mathrm{nectarivore}$; Om = omnivore. Key to suffixes: $\mathrm{Ae}=$ aerial; $\mathrm{Aq}=$ aquatic; $\mathrm{Ar}=$ arboreal; $\mathrm{Ba}=$ bark; $\mathrm{Fo}=$ foliage; $\mathrm{Fs}=$ fossorial; $\mathrm{Te}=$ terrestrial .

Please cite this article in press as: Wardwell, D.A. et al., A test of the cross-scale resilience model: Functional richness in Mediterraneanclimate ecosystems, Ecol. Complex. (2008), doi:10.1016/j.ecocom.2007.11.001 
Table A4 - Bird species distribution for Mediterranean-climate South Africa

\begin{tabular}{|c|c|c|c|}
\hline Latin name & Body mass & Aggregation & Functional group \\
\hline Estrilda astrilid & 0.875 & 1 & GrFo \\
\hline Nectarinia chalybea & 0.937 & 1 & $\mathrm{NeAe}$ \\
\hline Cisticola fulvicapilla & 0.954 & 1 & InTe \\
\hline Nectarinia violacea & 0.964 & 1 & NeFo \\
\hline Prinia maculosa & 1.000 & 1 & InFo \\
\hline Cisticola subruficapilla & 1.021 & 1 & InFo \\
\hline Sylvietta rufescens & 1.053 & 1 & InFo \\
\hline Apalis thoracica & 1.083 & 1 & InFo \\
\hline Batis capensis & 1.107 & 1 & InFo \\
\hline Cisticola tinniens & 1.111 & 1 & InTe \\
\hline Riparia paludicola & 1.127 & 1 & InAe \\
\hline Zosterops virens & 1.127 & 1 & $\mathrm{NeFo}$ \\
\hline Serinus canicollis & 1.140 & 1 & GrTe \\
\hline Saxicola torquata & 1.185 & 2 & InAe \\
\hline Parisoma subcaeruleum & 1.193 & 2 & InFo \\
\hline Hirundo rustica & 1.204 & 2 & InAe \\
\hline Euplectes orix & 1.211 & 2 & GrTe \\
\hline Serinus flaviventris & 1.212 & 2 & GrTe \\
\hline Nectarinia famosa & 1.233 & 2 & NeFo \\
\hline Euplectes capensis & 1.260 & 2 & GrTe \\
\hline Cercomela sinuata & 1.270 & 2 & InAe \\
\hline Hirundo rupestris & 1.279 & 2 & InAe \\
\hline Serinus sulphuratus & 1.283 & 2 & GrTe \\
\hline Parus afer & 1.297 & 2 & InBa \\
\hline Calandrella cinerea & 1.316 & 2 & InTe \\
\hline Motacilla capensis & 1.318 & 2 & InTe \\
\hline Hirundo albigularis & 1.328 & 2 & InAe \\
\hline Passer melanurus & 1.340 & 2 & GrTe \\
\hline Cercomela familiaris & 1.342 & 2 & InTe \\
\hline Emberiza capensis & 1.350 & 2 & GrTe \\
\hline Anthus novaeseelandiae & 1.384 & 3 & InTe \\
\hline Sigelus silens & 1.408 & 3 & InAe \\
\hline Serinus albogularis & 1.413 & 3 & GrTe \\
\hline Hirundo cucullata & 1.431 & 3 & InAe \\
\hline Anthus leucophrys & 1.431 & 3 & InTe \\
\hline Cossypha caffra & 1.455 & 3 & InTe \\
\hline Mirafra apiata & 1.487 & 3 & InTe \\
\hline Sphenoeacus afer & 1.497 & 3 & InTe \\
\hline Lybius leucomelas & 1.508 & 3 & HeFo \\
\hline Pycnonotus capensis & 1.597 & 4 & HeFo \\
\hline Promerops cafer & 1.606 & 4 & $\mathrm{NeFo}$ \\
\hline Oena capensis & 1.608 & 4 & GrTe \\
\hline Colius colius & 1.617 & 4 & HeFo \\
\hline Lanius collaris & 1.618 & 4 & InTe \\
\hline Ploceus capensis & 1.627 & 4 & InTe \\
\hline Apus barbatus & 1.631 & 4 & InAe \\
\hline Caprimulgus pectoralis & 1.674 & 5 & InAe \\
\hline Macronyx capensis & 1.677 & 5 & InTe \\
\hline Lanius ferrugineus & 1.688 & 5 & InTe \\
\hline Colius striatus & 1.708 & 5 & HeFo \\
\hline Colius indicus & 1.751 & 6 & HeFo \\
\hline Monticola rupestris & 1.778 & 6 & $\mathrm{InTe}$ \\
\hline Upupa epops & 1.788 & 6 & InTe \\
\hline Malaconotus zeylonus & 1.797 & 6 & InTe \\
\hline Creatophora cinerea & 1.826 & 6 & InTe \\
\hline Turdus olivaceus & 1.868 & 6 & InTe \\
\hline Apus melba & 1.881 & 6 & InAe \\
\hline Streptopelia senegalensis & 2.004 & 7 & GrTe \\
\hline Spreo bicolor & 2.021 & 7 & InTe \\
\hline Geocolaptes olivaceus & 2.079 & 7 & InTe \\
\hline Onychognathus morio & 2.124 & 7 & InTe \\
\hline Streptopelia capicola & 2.152 & 7 & GrTe \\
\hline Vanellus coronatus & 2.223 & 7 & InTe \\
\hline Falco tinnunculus & 2.304 & 7 & $\mathrm{CaAe}$ \\
\hline Elanus caeruleus & 2.522 & 8 & $\mathrm{CaAe}$ \\
\hline
\end{tabular}

Please cite this article in press as: Wardwell, D.A. et al., A test of the cross-scale resilience model: Functional richness in Mediterraneanclimate ecosystems, Ecol. Complex. (2008), doi:10.1016/j.ecocom.2007.11.001 


\section{Table A4 (Continued)}

\begin{tabular}{lccc} 
Latin name & Body mass & Aggregation & Functional group \\
\hline Bubulcus (=Ardeola) ibis & 2.529 & 8 & InTe \\
Columba guinea & 2.547 & 8 & GrTe \\
Francolinus africanus & 2.592 & 8 & HeTe \\
Burhinus capensis & 2.626 & 8 & InTe \\
Circus ranivorus & 2.705 & 8 & CaAe \\
Corvus albus & 2.723 & 8 & HeTe \\
Francolinus capensis & 2.814 & 8 & HeTe \\
Afrotis afra & 2.840 & 8 & InTe \\
Corvus capensis & 2.843 & 8 & InTe \\
Buteo buteo & 2.942 & 8 & CaAe \\
Corvus albicollis & 2.954 & 8 & InTe \\
Ardea melanocephala & 3.025 & 8 & InTe \\
Buteo rufofuscus & 3.066 & 8 & CaAe \\
Sagittarius serpantarius & 3.557 & 9 & InTe \\
Aquila verreauxi & 3.613 & 9 & CaAe \\
Otis denhami & 3.615 & 9 & InTe \\
\hline
\end{tabular}

Each distribution includes Latin names, log10-transformed body masses, body mass aggregation membership, and functional group code used in richness simulations. The first two letters (prefix) of the functional group code represent the diet component and the latter two letters (suffix) represent foraging strata. Key to prefixes: $\mathrm{Ca}=$ carnivore; $\mathrm{Gr}=$ granivore; $\mathrm{He}=$ herbivore; $\mathrm{In}=$ insectivore; $\mathrm{Ne}=\mathrm{nectarivore}$; Om = omnivore. Key to suffixes: $\mathrm{Ae}=$ aerial; $\mathrm{Aq}=$ aquatic; $\mathrm{Ar}=$ arboreal; $\mathrm{Ba}=$ bark; $\mathrm{Fo}=$ foliage; $\mathrm{Fs}=$ fossorial; $\mathrm{Te}=$ terrestrial.

Table A5 - Mammal species distribution for Mediterranean-climate California, USA

\begin{tabular}{|c|c|c|c|}
\hline Latin name & Body mass & Aggregation & Functional group \\
\hline Sorex ornatus & 0.698 & 1 & InTe \\
\hline Sorex vagrans & 0.707 & 1 & InTe \\
\hline Reithrodontomys megalotis & 1.049 & 1 & GrTe \\
\hline Peromyscus maniculatus & 1.299 & 2 & GrTe \\
\hline Peromyscus boylii & 1.329 & 2 & $\mathrm{HeAr}$ \\
\hline Peromyscus truei & 1.427 & 2 & GrTe \\
\hline Peromyscus californicus & 1.656 & 3 & GrTe \\
\hline Tamias obscurus & 1.748 & 3 & $\mathrm{HeAr}$ \\
\hline Dipodomys heermanni & 1.857 & 3 & GrTe \\
\hline Tamias merriami & 1.875 & 3 & GrTe \\
\hline Dipodomys venustus & 1.929 & 3 & GrTe \\
\hline Dipodomys elephantinus & 1.930 & 3 & GrTe \\
\hline Thomomys bottae & 2.049 & 3 & $\mathrm{HeFs}$ \\
\hline Neotoma lepida & 2.164 & 3 & HeTe \\
\hline Mustela frenata & 2.167 & 3 & CaTe \\
\hline Peromyscus eremicus & 2.276 & 3 & GrTe \\
\hline Neotoma fuscipes & 2.281 & 3 & $\mathrm{HeAr}$ \\
\hline Spermophilus beecheyi & 2.781 & 4 & HeTe \\
\hline Sylvilagus bachmani & 2.785 & 4 & $\mathrm{HeTe}$ \\
\hline Sylvilagus auduboni & 2.879 & 4 & HeTe \\
\hline Spilogale gracilis & 2.888 & 4 & CaTe \\
\hline Bassaricus astutus & 3.053 & 4 & $\mathrm{CaTe}$ \\
\hline Mephitis mephitis & 3.253 & 4 & InTe \\
\hline Urocyon cinereoargenteus & 3.548 & 5 & CaTe \\
\hline Procyon lotor psora & 3.557 & 5 & OmTe \\
\hline Taxidea taxus & 3.857 & 5 & $\mathrm{CaTe}$ \\
\hline Lynx rufus & 3.889 & 5 & CaTe \\
\hline Canis latrans & 4.102 & 5 & CaTe \\
\hline Odocoileus hemionus & 4.635 & 6 & $\mathrm{HeTe}$ \\
\hline Felis concolor & 4.754 & 6 & CaTe \\
\hline Felis onca & 5.061 & 6 & $\mathrm{CaTe}$ \\
\hline Ursos arctos & 5.190 & 6 & OmTe \\
\hline
\end{tabular}

Each distribution includes Latin names, log10-transformed body masses, body mass aggregation membership, and functional group code used in richness simulations. The first two letters (prefix) of the functional group code represent the diet component and the latter two letters (suffix) represent foraging strata. Key to prefixes: $\mathrm{Ca}=$ carnivore; $\mathrm{Gr}=$ granivore; $\mathrm{He}=$ herbivore; $\mathrm{In}=$ insectivore; $\mathrm{Ne}=\mathrm{nectarivore}$; Om $=$ omnivore. Key to suffixes: $\mathrm{Ae}=$ aerial; $\mathrm{Aq}=$ aquatic; $\mathrm{Ar}=$ arboreal; $\mathrm{Ba}=$ bark; $\mathrm{Fo}=$ foliage; $\mathrm{Fs}=$ fossorial; $\mathrm{Te}=$ terrestrial.

Please cite this article in press as: Wardwell, D.A. et al., A test of the cross-scale resilience model: Functional richness in Mediterraneanclimate ecosystems, Ecol. Complex. (2008), doi:10.1016/j.ecocom.2007.11.001 
Table A6 - Mammal species distribution for Mediterranean-climate South Africa

\begin{tabular}{|c|c|c|c|}
\hline Latin name & Body mass & Aggregation & Functional group \\
\hline Mus minutoides & 0.767 & 1 & HeTe \\
\hline Suncus varilla & 0.813 & 1 & InTe \\
\hline Dendromus melanotis & 0.826 & 1 & InTe \\
\hline Crocidura cyanea & 0.934 & 1 & InTe \\
\hline Dendromus mesomelas & 1.053 & 1 & InTe \\
\hline Malacothrix typica & 1.127 & 1 & HeTe \\
\hline Myosorex varius & 1.130 & 1 & InTe \\
\hline Acomys subspinosus & 1.325 & 2 & HeTe \\
\hline Steatomys krebsi & 1.380 & 2 & $\mathrm{HeTe}$ \\
\hline Graphiurus murinus & 1.450 & 2 & InTe \\
\hline Gerbillurus paeba & 1.511 & 2 & $\mathrm{HeTe}$ \\
\hline Rhabdomys pumilo & 1.559 & 2 & $\mathrm{HeTe}$ \\
\hline Macroscelides proboscideus & 1.582 & 2 & InTe \\
\hline Myomyscus verroxii & 1.613 & 2 & InTe \\
\hline Desmmodillus auricularis & 1.664 & 2 & HeTe \\
\hline Aethomys namequensis & 1.688 & 2 & HeTe \\
\hline Chrysochloris asiatica & 1.690 & 2 & InFs \\
\hline Amblysomus hottentotus & 1.832 & 3 & InFs \\
\hline Graphiurus ocularis & 1.838 & 3 & InTe \\
\hline Cryptomys hottentotus & 1.897 & 3 & HeFs \\
\hline Mystromys albicaudatus & 1.939 & 3 & HeTe \\
\hline Dasymys incomtus & 1.972 & 3 & HeTe \\
\hline Tatera afra & 1.987 & 3 & HeTe \\
\hline Otomys saundersiae & 2.013 & 3 & $\mathrm{HeTe}$ \\
\hline Otomys irroratus & 2.072 & 3 & HeTe \\
\hline Crocidura flavescens & 2.088 & 3 & InTe \\
\hline Otomys unisulcatus & 2.095 & 3 & HeTe \\
\hline Otomys laminatus & 2.176 & 3 & HeTe \\
\hline Georychus capensis & 2.338 & 4 & HeTe \\
\hline Poecilogale albinucha & 2.338 & 4 & $\mathrm{CaTe}$ \\
\hline Bathyergus suillus & 2.796 & 4 & $\mathrm{HeFs}$ \\
\hline Ictonyx striatus & 2.866 & 4 & InTe \\
\hline Herpestes pulverulenta & 2.901 & 4 & InTe \\
\hline Cynictis penicillata & 2.919 & 4 & InTe \\
\hline Pronolagus rupestris & 3.210 & 5 & HeTe \\
\hline Genetta tigrina & 3.270 & 5 & $\mathrm{CaTe}$ \\
\hline Genetta genetta & 3.279 & 5 & CaTe \\
\hline Lepus capensis & 3.310 & 5 & $\mathrm{HeTe}$ \\
\hline Vulpes chama & 3.423 & 5 & $\mathrm{CaTe}$ \\
\hline Procavia capensis & 3.480 & 5 & HeTe \\
\hline Atilax paludinosus & 3.531 & 5 & CaTe \\
\hline Lepus saxatilis & 3.556 & 5 & HeTe \\
\hline Felis libyca & 3.633 & 5 & $\mathrm{CaTe}$ \\
\hline Proteles cristatus & 3.840 & 6 & InTe \\
\hline Canis mesomelas & 3.898 & 6 & $\mathrm{CaTe}$ \\
\hline Mellivora capensis & 3.899 & 6 & CaTe \\
\hline Oreotragus oreotragus & 4.009 & 6 & HeTe \\
\hline Raphicerus melanotis & 4.011 & 6 & HeTe \\
\hline Felis caracal & 4.029 & 6 & $\mathrm{CaTe}$ \\
\hline Felis serval & 4.047 & 6 & $\mathrm{CaTe}$ \\
\hline Raphicerus campestris & 4.053 & 6 & HeTe \\
\hline Aonyx capensis & 4.061 & 6 & $\mathrm{CaAq}$ \\
\hline Hystrix africaeaustralis & 4.097 & 6 & HeTe \\
\hline Sylvicapra grimmia & 4.207 & 6 & HeTe \\
\hline Pelea capreolus & 4.352 & 7 & HeTe \\
\hline Papio ursinus & 4.365 & 7 & HeTe \\
\hline Panthera pardus & 4.416 & 7 & CaTe \\
\hline Hyaena brunnea & 4.583 & 8 & CaTe \\
\hline Orycteropus afer & 4.719 & 8 & InTe \\
\hline Damaliscus dorcas dorcas & 4.826 & 8 & HeTe \\
\hline Alcelaphus buselaphus & 5.134 & 9 & HeTe \\
\hline Panthera leo & 5.193 & 9 & CaTe \\
\hline Equus zebra & 5.388 & 9 & $\mathrm{HeTe}$ \\
\hline
\end{tabular}

Please cite this article in press as: Wardwell, D.A. et al., A test of the cross-scale resilience model: Functional richness in Mediterraneanclimate ecosystems, Ecol. Complex. (2008), doi:10.1016/j.ecocom.2007.11.001 


\section{Table A6 (Continued)}

\begin{tabular}{lccc} 
Latin name & Body mass & Aggregation & Functional group \\
\hline Taurotragus oryx & 5.587 & 9 & HeTe \\
Diceros bicornis & 5.939 & 9 & HeTe \\
\hline
\end{tabular}

Each distribution includes Latin names, log10-transformed body masses, body mass aggregation membership, and functional group code used in richness simulations. The first two letters (prefix) of the functional group code represent the diet component and the latter two letters (suffix) represent foraging strata. Key to prefixes: $\mathrm{Ca}=$ carnivore; $\mathrm{Gr}=$ granivore; He = herbivore; $\mathrm{In}=$ insectivore; $\mathrm{Ne}=\mathrm{nectarivore}$; Om = omnivore. Key to suffixes: $\mathrm{Ae}=$ aerial; $\mathrm{Aq}=$ aquatic; $\mathrm{Ar}=$ arboreal; $\mathrm{Ba}=$ bark; $\mathrm{Fo}=$ foliage; $\mathrm{Fs}=$ fossorial; $\mathrm{Te}=$ terrestrial.

Table A7 - Mammal species distribution for Mediterranean-climate southwestern Australia

\begin{tabular}{|c|c|c|c|}
\hline Latin name & Body mass & Aggregation & Functional group \\
\hline Tarsipes rostratus & 0.954 & 1 & $\mathrm{HeAr}$ \\
\hline Cercartetus concinnus & 1.114 & 1 & InAr \\
\hline Sminthopsis dolichura & 1.134 & 1 & InTe \\
\hline Sminthopsis crassicaudata & 1.176 & 1 & InTe \\
\hline Sminthopsis griseoventer & 1.243 & 1 & InTe \\
\hline Sminthopsis gilberti & 1.290 & 1 & InTe \\
\hline Sminthopsis granulipes & 1.398 & 1 & InTe \\
\hline Pseudomys albocinereus & 1.484 & 1 & HeTe \\
\hline Pseudomys nanus & 1.531 & 1 & HeTe \\
\hline Pseudomys occidentalis & 1.531 & 1 & HeTe \\
\hline Notomys alexis & 1.544 & 1 & GrTe \\
\hline Antichinus flavipes & 1.653 & 1 & InTe \\
\hline Pseudomys fieldi & 1.653 & 1 & HeTe \\
\hline Phascogale calura & 1.712 & 1 & InAr \\
\hline Notomys mitchelli & 1.716 & 1 & GrTe \\
\hline Parantechinus apicalis & 1.837 & 2 & InTe \\
\hline Pseudomys shortridgei & 1.845 & 2 & HeTe \\
\hline Notomys longicaudatus & 2.000 & 2 & GrTe \\
\hline Rattus tunneyi & 2.093 & 2 & HeTe \\
\hline Rattus fuscipes & 2.122 & 2 & InTe \\
\hline Phascogale tapoatafa & 2.287 & 3 & InAr \\
\hline Perameles bougainville & 2.354 & 3 & $\mathrm{HeTe}$ \\
\hline Myrmecobius fasciatus & 2.673 & 3 & InTe \\
\hline Hydromys chrysogaster & 2.833 & 4 & InAq \\
\hline Isoodon obesulus & 2.889 & 4 & InTe \\
\hline Pseudocheirus occidentalis & 3.000 & 4 & $\mathrm{HeAr}$ \\
\hline Dasyurus geoffroii & 3.041 & 4 & $\mathrm{CaTe}$ \\
\hline Potorus tridactylus & 3.041 & 4 & HeTe \\
\hline Lagorchestes hirsutus & 3.102 & 4 & HeTe \\
\hline Bettongia penicillata & 3.114 & 4 & $\mathrm{HeTe}$ \\
\hline Bettongia leseur & 3.176 & 4 & HeTe \\
\hline Lagostrophus fasciatus & 3.230 & 4 & HeTe \\
\hline Trichosurus vulpecula & 3.419 & 5 & $\mathrm{HeAr}$ \\
\hline Setonix brachyurus & 3.512 & 5 & $\mathrm{HeTe}$ \\
\hline Onychogalea lunata & 3.544 & 5 & $\mathrm{HeTe}$ \\
\hline Petrogale lateralis & 3.602 & 5 & HeTe \\
\hline Tachyglossus aculeatus & 3.653 & 5 & InTe \\
\hline Macropus eugenii & 3.813 & 5 & $\mathrm{HeTe}$ \\
\hline Macropus irma & 3.903 & 5 & HeTe \\
\hline Canis lupus & 4.225 & 6 & CaTe \\
\hline Macropus robustus & 4.327 & 6 & HeTe \\
\hline Macropus fuliginosus & 4.345 & 6 & HeTe \\
\hline
\end{tabular}

Each distribution includes Latin names, log10-transformed body masses, body mass aggregation membership, and functional group code used in richness simulations. The first two letters (prefix) of the functional group code represent the diet component and the latter two letters (suffix) represent foraging strata. Key to prefixes: $\mathrm{Ca}=$ carnivore; $\mathrm{Gr}=$ granivore; $\mathrm{He}=$ herbivore; $\mathrm{In}=$ insectivore; $\mathrm{Ne}=\mathrm{nectarivore}$; Om $=$ omnivore. Key to suffixes: $\mathrm{Ae}=$ aerial; $\mathrm{Aq}=$ aquatic; $\mathrm{Ar}=$ arboreal; $\mathrm{Ba}=$ bark; $\mathrm{Fo}=$ foliage; $\mathrm{Fs}=$ fossorial; $\mathrm{Te}=$ terrestrial.

Please cite this article in press as: Wardwell, D.A. et al., A test of the cross-scale resilience model: Functional richness in Mediterraneanclimate ecosystems, Ecol. Complex. (2008), doi:10.1016/j.ecocom.2007.11.001 
Table A8 - Mammal species distribution for Mediterranean-climate Chile

\begin{tabular}{|c|c|c|c|}
\hline Latin name & Body mass & Aggregation & Functional group \\
\hline Marmosa elegans & 1.481 & 1 & InTe \\
\hline Oryzomys longicaudatus & 1.560 & 1 & GrTe \\
\hline Akodon olivaceus & 1.639 & 1 & GrTe \\
\hline Phyllotis darwini & 1.789 & 2 & HeTe \\
\hline Akodon longipilis & 1.796 & 2 & InTe \\
\hline Chelemys macronyx & 1.865 & 2 & GrTe \\
\hline Euneomys mordax & 1.914 & 2 & HeTe \\
\hline Octodon bridgesi & 1.966 & 2 & HeTe \\
\hline Spalacopus cyanus & 2.011 & 2 & HeFs \\
\hline Aconaemys fuscus & 2.090 & 2 & HeTe \\
\hline Ctenomys maulinus & 2.215 & 2 & HeTe \\
\hline Octodon degus & 2.264 & 2 & HeAr \\
\hline Abrocoma bennetti & 2.363 & 2 & HeAr \\
\hline Octodon lunatus & 2.367 & 2 & HeTe \\
\hline Lagidium viscacia & 3.188 & 3 & HeTe \\
\hline Galictis guia & 3.199 & 3 & CaTe \\
\hline Conepatus chinga & 3.275 & 3 & InTe \\
\hline Felis Guigna & 3.348 & 3 & CaTe \\
\hline Felis Colocolo & 3.470 & 3 & $\mathrm{CaAr}$ \\
\hline Myocaster coypus & 3.579 & 3 & $\mathrm{HeAq}$ \\
\hline Dusicyon griseus & 3.601 & 3 & CaTe \\
\hline Lutra felina & 3.653 & 3 & InAq \\
\hline Dusicyon culpaeus & 3.867 & 3 & CaTe \\
\hline Pudu puda & 3.989 & 3 & $\mathrm{HeTe}$ \\
\hline Felis concolor & 4.549 & 4 & CaTe \\
\hline Hippocamelus bisulcus & 4.845 & 4 & $\mathrm{HeTe}$ \\
\hline Lama guanicoe & 5.079 & 4 & HeTe \\
\hline
\end{tabular}

Table A9 - Mammal species distribution for Mediterranean-climate Spain

\begin{tabular}{lccc} 
Latin name & Body mass & Aggregation & Functional group \\
\hline Suncus etruscus & 0.352 & 1 & InTe \\
Sorex minutus & 0.477 & 1 & InTe \\
Micromys minutus & 0.756 & 1 & GrTe \\
Sorex granarius & 0.796 & 1 & GrTe \\
Crocidura russula & 0.806 & 1 & InTe \\
Crocidura suaveolens & 0.825 & 1 & InTe \\
Mus spretus & 1.090 & 2 & GrTe \\
Neomys fodiens & 1.114 & 2 & InAq \\
Neomys anomalus & 1.134 & 2 & InTe \\
Pitymys lusitanicus & 1.212 & 2 & HeTe \\
Microtus arvalis & 1.262 & 2 & HeFs \\
Mus domesticus & 1.283 & 2 & GrTe \\
Clethrionomys glareolus & 1.288 & 2 & HeTe \\
Apodemus sylvaticus & 1.344 & 2 & InTe \\
Microtis agrestis & 1.344 & 2 & HeTe \\
Pitymys duodecimcostatus & 1.345 & 2 & HeTe \\
Talpa caeca & 1.505 & 3 & InFs \\
Microtus nivalis & 1.591 & 3 & $\mathrm{HeTe}$ \\
Galemys pyrenaicus & 1.760 & 3 & InAq \\
Talpa europaea & 1.881 & 3 & InFs \\
Talpa romana & 1.966 & 3 & InFs \\
Eliomys quercinus & 1.980 & 3 & HeTe \\
Rattus rattus & 2.092 & 3 & HeTe \\
Mustela nivalis & 2.150 & 3 & CaTe
\end{tabular}

Please cite this article in press as: Wardwell, D.A. et al., A test of the cross-scale resilience model: Functional richness in Mediterraneanclimate ecosystems, Ecol. Complex. (2008), doi:10.1016/j.ecocom.2007.11.001 


\section{Table A9 (Continued)}

\begin{tabular}{|c|c|c|c|}
\hline Latin name & Body mass & Aggregation & Functional group \\
\hline Arvicola sapidus & 2.230 & 3 & $\mathrm{HeAq}$ \\
\hline Myoxis glis & 2.284 & 3 & $\mathrm{HeAr}$ \\
\hline Sciurus vulgaris & 2.398 & 3 & $\mathrm{HeAr}$ \\
\hline Rattus norvegicus & 2.455 & 3 & HeTe \\
\hline Erinaceus europaeus & 2.805 & 4 & InTe \\
\hline Erinaceus algirus & 2.845 & 4 & InTe \\
\hline Mustela putorius & 3.000 & 4 & $\mathrm{CaTe}$ \\
\hline Martes foina & 3.000 & 4 & CaTe \\
\hline Oryctolagus cuniculus & 3.196 & 5 & HeTe \\
\hline Genetta genetta & 3.236 & 5 & CaTe \\
\hline Lepus capensis & 3.310 & 5 & $\mathrm{HeTe}$ \\
\hline Lepus granatensis & 3.334 & 5 & HeTe \\
\hline Felis silvestris & 3.385 & 5 & $\mathrm{CaTe}$ \\
\hline Herspestes ichneumon & 3.474 & 5 & CaTe \\
\hline Vulpes vulpes & 3.678 & 6 & CaTe \\
\hline Lutra lutra & 3.796 & 6 & $\mathrm{CaAq}$ \\
\hline Meles meles & 3.964 & 6 & InTe \\
\hline Lynx pardinus & 4.043 & 6 & CaTe \\
\hline Macaca sylvanus & 4.049 & 6 & HeTe \\
\hline Capreolus capreolus & 4.079 & 6 & HeTe \\
\hline Castor fiber & 4.145 & 6 & $\mathrm{HeTe}$ \\
\hline Canis lupus & 4.632 & 7 & $\mathrm{CaTe}$ \\
\hline Sus scrofa & 4.740 & 7 & HeTe \\
\hline Capra pyrenaica & 4.760 & 7 & $\mathrm{HeTe}$ \\
\hline Cervus elaphus & 5.176 & 7 & HeTe \\
\hline Ursus arctos & 5.247 & 7 & HeTe \\
\hline
\end{tabular}

Each distribution includes Latin names, log10-transformed body masses, body mass aggregation membership, and functional group code used in richness simulations. The first two letters (prefix) of the functional group code represent the diet component and the latter two letters (suffix) represent foraging strata. Key to prefixes: $\mathrm{Ca}=$ carnivore; $\mathrm{Gr}=$ granivore; He = herbivore; In = insectivore; $\mathrm{Ne}=\mathrm{nectarivore}$; Om = omnivore. Key to suffixes: $\mathrm{Ae}=$ aerial; $\mathrm{Aq}=$ aquatic; $\mathrm{Ar}=$ arboreal; $\mathrm{Ba}=$ bark; $\mathrm{Fo}=$ foliage; $\mathrm{Fs}=$ fossorial; $\mathrm{Te}=$ terrestrial.

\section{R E F E R E N C E S}

Allen, C.R., Holling, C.S., 2002. Cross-scale structure and scale breaks in ecosystems and other complex systems. Ecosystems 5, 315-318.

Allen, C.R., Forys, E.A., Holling, C.S., 1999. Body mass patterns predict invasions and extinctions in transforming landscapes. Ecosystems 2, 114-121.

Allen, C.R., Epperson, D., Garmestani, A., 2004. The impacts of fire ants on wildlife: a decade of research. Am. Midl. Nat. 152, 88-103.

Allen, C.R., Gunderson, L., Johnson, A.R., 2005. The use of discontinuities and functional groups to assess relative resilience in complex systems. Ecosystems 8, 958-966.

Blakers, M., Davies, S.J.J.F., Reilly, P.N. (Eds.), 1984. The Atlas of Australian Birds. Melbourne University Press, Carlton, Victoria.

Brown, L.H., Urban, E.K., Newman, K. (Eds.), 1982. The Birds of Africa, vol. 1. Academic Press London Inc., London.

Cheylan, G., 1991. Patterns of Pleistocene turnover, current distribution and speciation among Mediterranean mammals. In: Groves, R.H., Di Castri, (Eds.), Biogeography of Mediterranean Invasions. Cambridge University Press, Cambridge, pp. 227-262.

Coulon, A., Cosson, J.F., Angibault, J.M., Cargnelutti, B., Galan, M., Morellet, N., Petit, E., Aulagnier, S., Hewison, A.J.M., 2004. Landscape connectivity influences gene flow in a roe deer population inhabiting a fragmented landscape: an individual-based approach. Mol. Ecol. 13, 2841-2850.

Cramp, S. (Ed.), 1978-1994. Handbook of the Birds of Europe the Middle East and North Africa, 9 volumes. Oxford University Press, New York.
Davis, G.W., Richardson, D.M. (Eds.), 1995. Mediterranean-Type Ecosystems: the Function of Biodiversity. Springer-Verlag, New York.

Di Castri, F., Mooney, H.A., 1973. Mediterranean Type Ecosystems: Origins and Structure. Springer-Verlag, New York.

Dunning Jr., J.B., 1993. CRC Handbook of Avian Body Masses. CRC Press, Ann Arbor, MI.

Ehrlich, P.R., Dobkin, D.S., Wheye, D., 1988. The Birder's Handbook: a Field Guide to the Natural History of North American Birds. Simon and Schuster Inc., New York.

Fisher, R.A., 1954. Statistical Methods for Research Workers, 12th ed. Oliver and Boyd, Edinburgh, UK.

Folke, C., Carpenter, S., Walker, B., Scheffer, M., Elmqvist, T., Gunderson, L., Holling, C.S., 2004. Regime shifts, resilience, and biodiversity in ecosystem management. Ann. Rev. Ecol. Evol. Syst. 35, 557-581.

Fry, C.H., Keith, S., Urban, E.K., 1988. The Birds of Africa, vol. 3. Academic Press London Inc., London.

Fry, C.H., Keith, S., Urban, E.K., 2000. The Birds of Africa, vol. 6. Academic Press London Inc., London.

Fry, C.H., Keith, S., Urban, E.K., 2004. The Birds of Africa, vol. 7. Academic Press London Inc., London.

Gunderson, L.H., 2000. Ecological resilience-in theory and application. Ann. Rev. Ecol. Syst. 31, 425-439.

Gunderson, L.H., Holling, C.S., 2002. Panarchy: Understanding Transformations in Human and Natural Systems. Island Press, Washington, DC.

Holling, C.S., 1973. Resilience and the stability of ecological systems. Ann. Rev. Ecol. Syst. 4, 1-23.

Holling, C.S., 1992. Cross-scale morphology, geometry, and dynamics of ecosystems. Ecol. Mon. 62, 447-502.

Jameson, E.W., Peeters, H.J., 1988. California Mammals. University of California Press, Berkeley, CA. 
Kalin Arroyo, M.T., Zedler, P.H., Fox, M.D., 1995. Ecology and Biogeography of Mediterranean Ecosystems in Chile, California, and Australia. Springer-Verlag, New York.

Keith, S., Urban, E.K., Fry, C.H., 1992. The Birds of Africa, vol. 4. Academic Press London Inc., London.

Lavorel, S., 1999. Ecological diversity and resilience of Mediterranean vegetation to disturbance. Div. Dist. 5, 3-13.

MacDonald, D.W., Barrett, P., 2001. Mammals of Europe. Princeton University Press, Princeton, NJ.

McCarthy, M.A., Possingham, H.P., Day, J.P., Tyre, A.J., 2001. Testing the accuracy of population viability analysis. Con. Bio. 15, 1030-1038.

Miller, S., 1980. Human influences on the distribution and abundance of wild Chilean mammals: prehistoric-present. Ph.D. Disssertation, University of Washington.

Peterson, G.D., 2002. Estimating resilience across landscapes. Con. Ecol. 6 (1), 17.

Peterson, G., Allen, C.R., Holling, C.S., 1998. Ecological resilience, biodiversity, and scale. Ecosystems 1, 6-18.

Quinn, R.D., 1990. Habitat preferences and distribution of mammals in California chaparral. Research Paper PSW-202. Pacific Southwest Research Station, U.S.D.A. Forest Service, Berkeley, CA.

Redford, K.H., Eisenberg, J.F., 1992. Mammals of the Neotropics. vol. 2. The Southern Cone. University of Chicago Press, Chicago, IL.

Restrepo, C., Renjifo, L.M., Marples, P., 1997. Frugivorous birds in fragmented neotropical montane forests: landscape pattern and body mass distribution. In: Laurance, W.F., Bierregaard, R.O., Moritz, C. (Eds.), Tropical Forest Remnants: Ecology, Management and Conservation of Fragmented Communities. University of Chicago Press, Chicago, IL, pp. 171-189.

SAS Institute Inc., 1999. SAS/STAT user's guide, Version 8, vol. 2. SAS Institute Inc., Cary, NC.
Saunders, D.A., Ingram, J.A., 1995. Birds of Southwestern Australia. Surrey Beatty and Sons Pty Limited, New South Wales.

Silva, M., Downing, J.A., 1995. CRC Handbook of Mammalian Body Masses. CRC Press, Ann Arbor, MI.

Silverman, B.W., 1981. Using kernel density estimates to investigate multimodality. J. Roy. Stat. Soc. 43, 97-99.

Smithers, R.H.N., 1983. The Mammals of the Southern African Subregion. University of Pretoria, South Africa.

Strahan, R. (Ed.), 1995. Mammals of Australia. Smithsonian Inst. Press, Washington, DC.

Stow, C., Allen, C.R., Garmestani, A.S., 2007. Evaluating discontinuities in complex systems: toward quantitative measures of resilience. Ecology and Society 12 (1), 26 [online]. URL: http://www.ecologyandsociety.org/vol12/iss1/art26/.

Turner, T.G., Gardner, R.H., O’Neill, R.V., 2001. Landscape Ecology in Theory and Practice. Springer-Verlag, New York.

Unitt, P., 1984. The birds of San Diego county. Memoir 13, San Diego Society of Natural History. United States Fish and Wildlife Service. (1991). Endangered and threatened wildlife and plants (50 CFR 17.11 and 17.12). United States Department of the Interior, Washington, DC.

Urban, E.K., Fry, C.H., Keith, S., 1986. The Birds of Africa, vol. 2. Academic Press London Inc., London.

Urban, E.K., Fry, C.H., Keith, S., 1997. The Birds of Africa, vol. 5. Academic Press London Inc., London.

Vignieri, S.N., 2005. Streams over mountains: influence of riparian connectivity on gene flow in the Pacific jumping mouse (Zapus trinotatus). Mol. Ecol. 14, 1925-1937.

Wilson, D.E., Ruff, S. (Eds.), 1999. The Smithsonian Book of North American Mammals. Smithsonian Institution Press, Washington, DC.

Winterbottom, J.M., 1966. Ecological distribution of the birds in the indigenous vegetation of the southwestern cape. Ostrich 37, 76-91. 